\title{
INSULATION INTERLAMINAR SHEAR STRENGTH TESTING WITH COMPRESSION AND IRRADIATION*
}

\author{
T. J. McManamy \\ Oak Ridge National Laboratory, Oat Ridge, Tennessec 37831-8071 \\ J. E. Brasier \\ Idaho National Engineering Laboratsry, Idaho Falls, Idaho 83415 \\ P. Snook \\ Princeton University, Princeton, New Jersey 08540
}

CONF-891007--26

\section{ABSTRACT}

The Compact Ignition Tolamak (CIT) project identified the need for research and development for the insulation to be used in the toroidal field coils. The requirements included tolerance to a combination of high compression ( $380 \mathrm{MPa}$ ) and shear ( $83 \mathrm{MPa}$ shear streas) and a high radiation dose (approximately $10^{10} \mathrm{rad}$ ). Samples of laminate-type sheet material were obtained from commercial vendors. The materials included various combinations of epory, polyimide, Eglass, S-glass, and $\boldsymbol{T}$-glass. The $\mathrm{T}$-glass was in the form of a thre-dimensional (3-D) weave. The first tests were with $50 \times 25 \times 1 \mathrm{~mm}$ samples. These materials were loaded in compreasion and then to failure in shear. At 345-MPa compression, the interlaminar shear strength was generally in the range of 110 to $110 \mathrm{MPa}$ for the differen: materials. A smaller sample configuration was developed for irradiation testing ( 13 by $13 \mathrm{~mm}$ ). The data before irradiation were similar to those for the larger samples but approximately $10 \%$ lower. Limited fatigue testing was also performed by cycling the shear load. No reduction in shear strength was found after 50,000 cycles at $90 \%$ of the failure stress. Because of space limitations, only three mcierials were chosen for irradiation: two polyimide systems and one epory system. All used boron-free glass. The small shear/compression samples and some flexure specimens were irradiated to $4 \times 10^{9}$ and $2 \times 10^{10} \mathrm{rad}$ in the Advanced Technology Reactor (ATR) at Idaho National Engineering Laboratory (INEL). A lead shield was used to ensure that the majority of the dose was from neutrons. The shear strength with compression before and after irradiation at the lower dose was determined. Flexure strength and the results from irradiation at the higher dose level will be available in the near future.

\section{INTRODUCTION}

A number of commercial vendors supply glossreinforced insulation in the form of large sheets, with sizes up to approximately 3 by $1.2 \mathrm{~m}$ available in a thickness of $1 \mathrm{~mm}$. Fifteen gamples of material from six vendors were obtained for mechanical testing. The principal test of interest was combined shear and compression. The test configurations are described below. In general, the materials were first screened by testing 25.4 by $50.8-\mathrm{mm}$ samples with varying compressive loads. A smaller test configuration for use with irradiated samples was then developed using 12.7by 12.7 -mm (0.5- by 0.5-in.) samples.

Irradiations at dose levels of $4 \times 10^{9}$ and $2 \times 10^{10} \mathrm{rad}$ are complete. However, testing is still in progress. Preliminary results for combined shear and compression loading for the lower dose level are presented.

The material combinations tested in the first series of screening tests are given in Table I. The term

Table I. Materialn teted in fint cerie of wereeaing tente

\begin{tabular}{|c|c|c|c|}
\hline Material & Revin & Oln type & Vendor \\
\hline Speulred-s & Binmeleimide & $5-2$ & Span \\
\hline Sponlred-K & Bingeleimide & Kevlar 20 & \\
\hline $\mathbf{a - 3 0}$ & Bimaleimide & $\mathbf{E}$ & Nor: \\
\hline $3-D$ & Epowy & E, 3-D mence & Shiliabinec \\
\hline PQ2-1 & Bpary & $\mathrm{E}, \mathbf{3 - D}$ meare & Shitinhime \\
\hline PQ1-2 & Epasy & $E, 3-0$ mente & Shitiabion \\
\hline PG3-1 & Epary & $T_{*} \& 3-D$ weare & Shiliahime \\
\hline Pog-1 & Bimaleimide & $\mathrm{T}, 3 \mathrm{D}$ meave & Shitithime \\
\hline GE-803 & Phenolic & $\mathbf{E}$ & NVP* \\
\hline P1-1225 & Bimaleimide & $\mathbf{E}$ & NVF \\
\hline G-215 & Epong & $\mathbf{E}$ & Electro-Isoin $f$ \\
\hline OR-67 & Epory & $\boldsymbol{E}$ & ABB: \\
\hline OR-68 & Epary & $\mathbf{E}$ & $\mathbf{A B B}$ \\
\hline (No name) & Bistandeimide & $\mathbf{E}$ & $\mathbf{A B B}$ \\
\hline
\end{tabular}

- Spanldirg Compodite Company, Toaswande, N.Y.

'Norplex Division, UOP Inc., La Crome, Will.

eghibinhime Canva Co., Ltd., Shigh, Japan.

dT-giem (a product of Nitto Bonebi Co., Ltd., Nittobo Gle-fber Divisioa) is a boran-free dan aimilac to S-glam.

- NVF Co., Kenaet Square, P.

$f$ U.S. dintribator: Pranidin Pibre Lumiter Corp., New Hyde Park, N.Y.

ASEA Brown Boveri Technologo, Inc., North Brunumiek, N.J.

"Research sponsored by the Office of Fusion Energy, U.S. Department of Energy, unde: contract DE $1105-840 R 21400$ with Martin Marietta Energy Systems, Inc. 
"polyimice" has been used in the literature for both pure polyimide systems and for bismaleimide systems, which have a slightly different ehemistry with a higher average hydrogen content.

\section{SCREENING TEST CONFIGURATIONS}

The screening tesis were done at the Material Test Laboratory of Princeton Plasma Physics Laboratory. Figures 1 and 2 show the two test devices. Both use

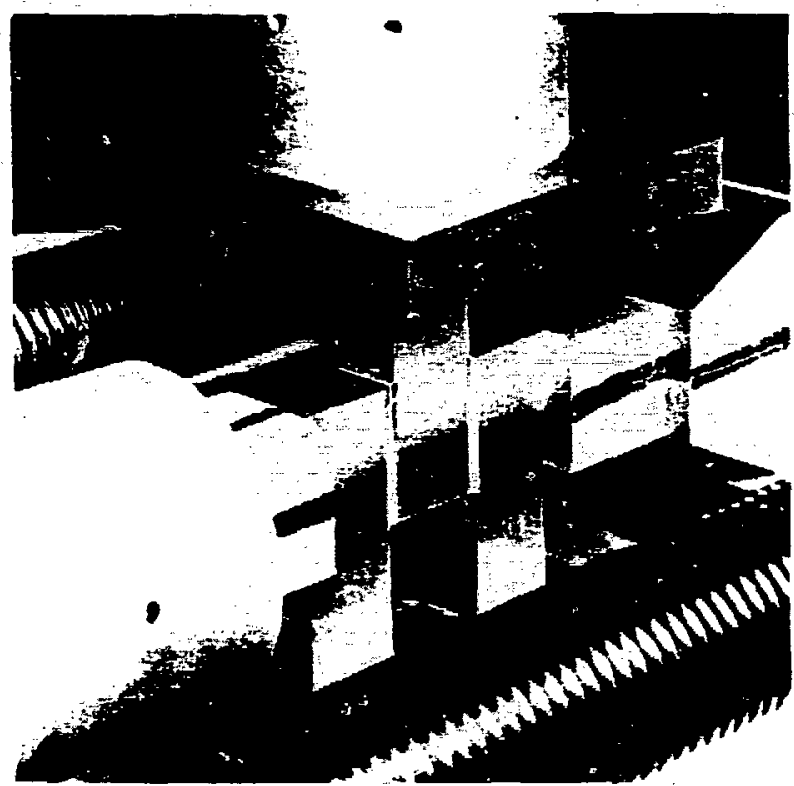

Fig. 1. Biaxial test device for 25.4 by $50.2-\mathrm{mm}$ samples.

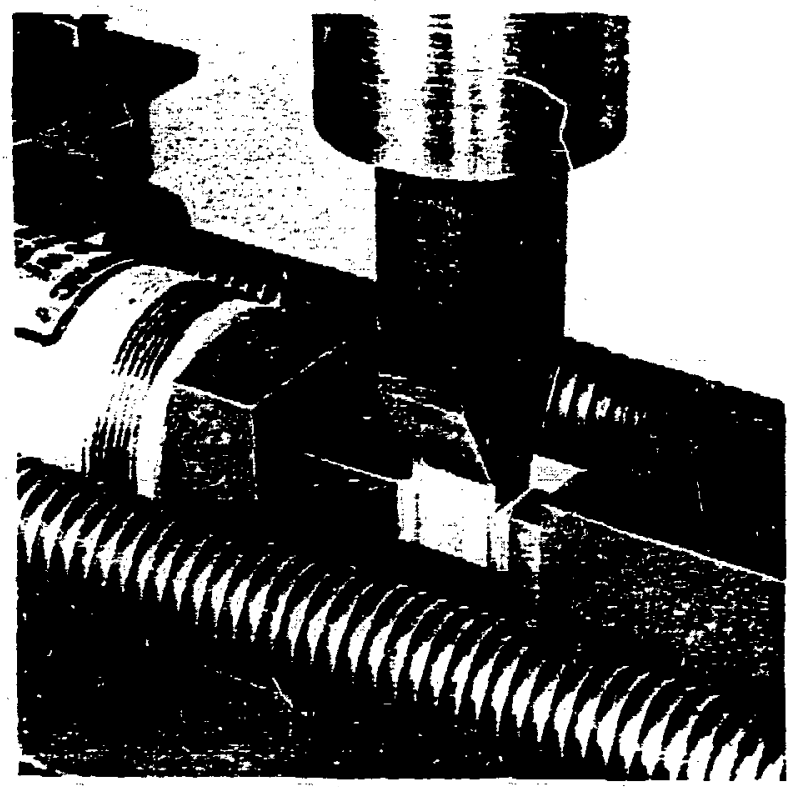

Fig. 2. Biarial test device for 12.7- by 12.7-mm samples. the same test method. Two insulation samples are tested simultaneously. Each sample has a grit-blasted, 2-mm-thick (0.080-in.) Inconel backing piece on each side. These assemblies are placed on each side of a central steel block. The compressive load is applied first through the two outside steel blocks. This load is produced by a hydraulic piston and threaded roda suspended around the samples. The shear load is applied on the central block and reacted by vertical supports on the side blocks. An important feature of this configuration is that shear strain is not coupled to the compressive strain. If the shear strength integrity is lost, the sample will fail catastrophically.

Finite element stress analysis showed significant gradients and stress concentrations near the edges of the samples $[1,2]$. The test method does, however, appear to give a good qualitative comparigon between different materials, and at high compression levels the failure mode is frequently pure interlaminar shear, as shown in Fig. 3. The test results given here are in terms of the average stress levels.
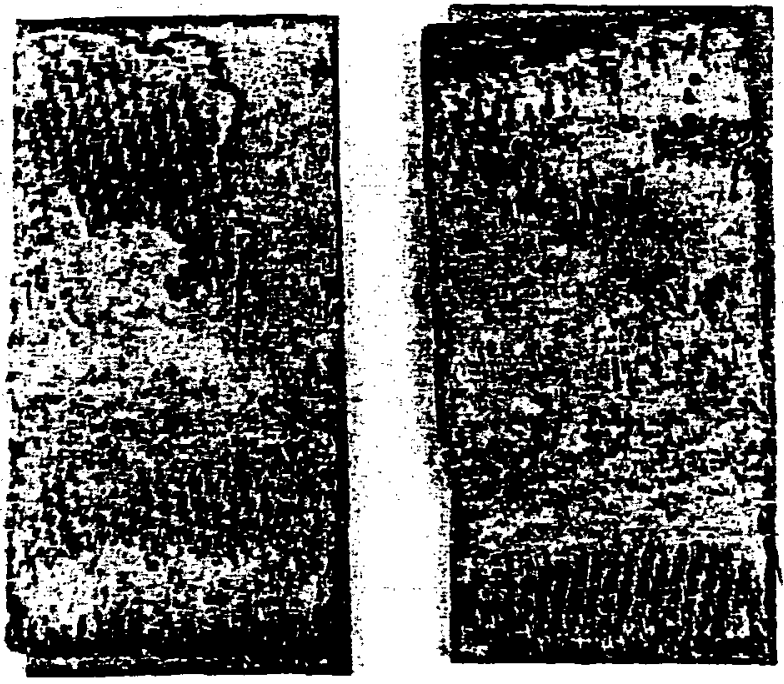

Fig. 3. Interiaminar shear failure of Spaulrad-S.

\section{TEST RESULTS}

Testing with the larger device was done at average compressions of 69,207 , and $345 \mathrm{MPa}(10,30$, and $50 \mathrm{ksi}$ ). Two pairs of samples were tested at each level. The compressive load was applied first, and then the shear load was increased until failure. At 69 $\mathrm{MPa}$, all materials failed by slipping at the interface between the Inconel and the insulation. The effective coefficient of friction varied between 0.43 and 0.71 for the different materials. With 207-MPa compression, all of the materials sheared at gtresses between 90 and 
104 MPa except for Spaulrad-K, which reached only $\simeq 65 \mathrm{MPa}$. (This material also showed significantly lower shear strength than the other materials at 345MPa compression and was eliminated from further testing.) Figure 4 summarizes the test results with 345-MPa compression for both size samples. The values shown are the average of two pairs for the larger samples and three pairs for the smaller samples. Both configurations show the same trends, with the smaller samples having approximately $10 \%$ lower shear strength. In genersl, all of the materials demonstrated very high interlaminar shear strengths with the high compressive loads.

Samples of PG3-1 material were also tested in the fill direction. They showed a $9 \%$ lower strength.

Spaultad-S and PG5-1 give a direct comparison of two-dimensional (2-D) vs 3-D weave performance for systems with nearly the same glass fractions and resin systems. The $3-D$ weave shows $\simeq 15 \%$ higher average shear strength with 345-MPa compression. The failure modes are also different; the Spaulrad produced a true interlaminar shear, separating between two of the five layers of glass, while the 3-D weave failure was more of a tearing through the thickness.

Figure 5 shows the shear strength vs compression for Spaulrad-S in both test configurations. Also shown is the result for the test of three pairs of the

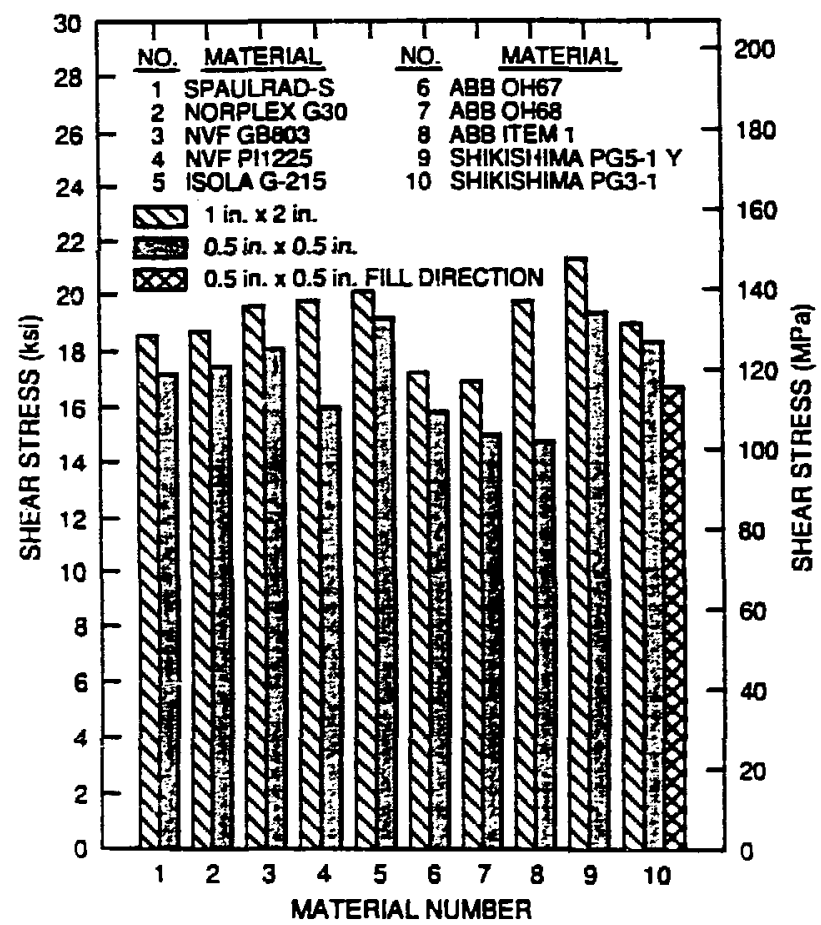

Fig. 4. Average interlaminar shear strengths of sheet materials under 50-ksi compression.

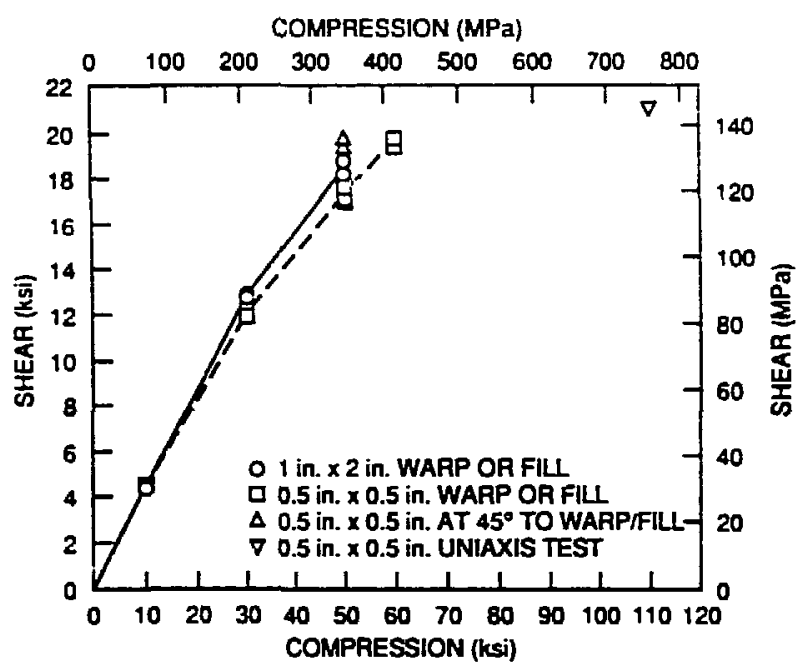

Fig. 5. Spaulrad-S interlaminar shear strength vg compression.

smaller samples that were cut at $45^{\circ}$ to the warp or fill direction. These samples consistently showed an incresse in strength (averaging $13 \%$ ) in this direction. A dats point is also included for the single-axis test device described below.

\section{SINGLE-AXIS TEST DEVICE}

Small samples were tested in a configuration in which the shear and compressive stress were applied simultaneously with a single-axis test machine, shown in Fig. 6. The concept was to have a sample on each side of a wedge. The angle of the wedge was chosen to give the same ratio of shear to compression as expected in the CIT derice. The wedge was restrained in the horizontal direction only by the shear strength of the two insulation samples. The same type of Inconel backing pieces with the grit-blasted finish were used on each side of the samples. In a test of Spaulrad-S with this device, failure occurred at 758-MPa compression and 145-MPa shear. The failure was pure interlaminar shear. The test was repeated once with similar results ( $8 \%$ higher strength). Handling of the samples was difficult, however, and this test configuration was not developed further.

\section{FATIGUE TESTING}

Three tests were performed on the samples of Spaulrad-S in which the shear load was cycled at $1 \mathrm{~Hz}$ with a constant compressive stress of $345 \mathrm{MPa}$. The first set of two samples was tested for 3000 cycles with a marimum shear stress of $61 \mathrm{MPa}(50 \%$ of the static 


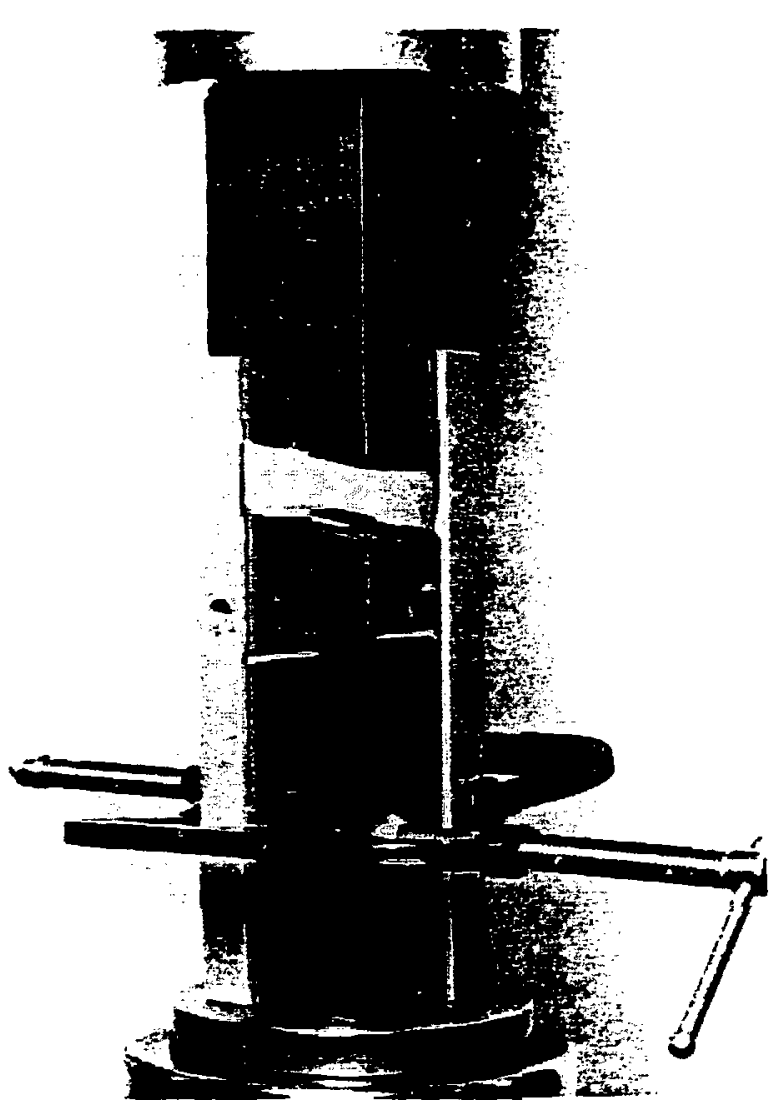

Fig. 6. Single-axis test device with 12.7 -by $12.7-\mathrm{mm}$ samples. External clamps are used oply for alignment and then removed.

strength) and a minimum of $5 \mathrm{MPa}$. The samples did not fail, and the maximum shear stress was increased to $91 \mathrm{MPa}$ for 3000 cycles. Another increase was then made to $109 \mathrm{MPa}$, and 6000 cycles were performed without fnilure. The shear stress was then increased to produce single-cycle failure, which occurred at 128 $\mathrm{MPa}$, actually slightly higher than the static strength before cycling. A second set of samples produced similar results. A third test was done using a maximum shear stress of $109 \mathrm{MPa}$. After 48,000 cycles, the test was terminated and a static test was performed. The shear strength was $125 \mathrm{MPa}$.

A fatigue test was also performed with the singleaxis device to cycle both the compressive and shear loads. At $414-\mathrm{MPa}$ compression with $79-\mathrm{MPa}$ shear stress, 18,000 cycles were performed without failure. With this material, it appeared that the only significant effect of cyclic shear stress at these levels was to seat the samples better with the grit-blasted Inconel surfaces.

\section{IRRADIATION TESTING}

\section{Materials}

The materials selected for irradiation testing are described in Table II. A primary consideration was to avoid including E-glass, which contains boron, because insulation using glass with boron performs poorly when exposed to a typical reactor thermal neutron flux $[3,4]$. Spaulrad-S and PG5-1 were chosen because both use a bismaleimide resin, which has shown good radiation resistance. Shikishima has also reported improved radiation resistance with 3-D weave materials $[5]$, and a direct comparison can be made with a 2-D system. The third material used an epoxy resin with an aromatic amine hardener.

\section{Irradiation Facility}

Samples were irradiated in ATR at INEL (operated by EG\&G). This facility has been used previously for irradiation and teating of insulation, including Spaulrad-S [3]. Two aluminum sample capsules were

Table II. Rad-I test materials

\begin{tabular}{|c|c|c|c|}
\hline & & Material & \\
\hline & Spaulrad-S & PG5-1 & PG3-1 \\
\hline $\begin{array}{l}\text { Resin } \\
\text { Hardener }\end{array}$ & $\begin{array}{l}\text { Bismaleimide (Kerimid 601) } \\
\text { None }\end{array}$ & $\begin{array}{l}\text { Bismaleimide triaxine } \\
\text { None }\end{array}$ & $\begin{array}{l}\text { Bisphenol-A } \\
\text { Aromatic amine }\end{array}$ \\
\hline $\begin{array}{l}\text { Fiber } \\
\text { Material } \\
\text { Preparation } \\
\text { Form }\end{array}$ & $\begin{array}{l}\text { S-2 glass } \\
\text { Silane } \\
\text { Fabric }\end{array}$ & $\begin{array}{l}T \text {-glass } \\
\text { Epory silane } \\
\text { 3-D weave }\end{array}$ & $\begin{array}{l}\text { T-glass } \\
\text { Epoxy silane } \\
\text { 3-D weave }\end{array}$ \\
\hline Resin, wt \% & 26 & 33 & 29 \\
\hline $\begin{array}{l}\text { Glass, vol. \% } \\
\text { Warp direction } \\
\text { Fill direction } \\
\text { Thickness direction } \\
\end{array}$ & & $\begin{array}{l}57 \\
34 \\
9\end{array}$ & $\begin{array}{l}57 \\
34 \\
9\end{array}$ \\
\hline
\end{tabular}


fabricated with an inside diameter of $23.6 \mathrm{~mm}$. Each capsule contained eighteen $12.7 \times 12.7 \times 1.0 \mathrm{~mm}$ shear/compression samples and six $50 \times 5 \times 1 \mathrm{~mm}$ flexure specimens of each material. The samples were packed with aluminum foil and powder for heat conduction to the outer surface of the cylinder to limit the peak temperature to $<340 \mathrm{~K}$. The lengths of the capsules were sized to limit the pressure due to outgassing, based on the outgassing rates quoted in Ref. [6] and dose levels of $10^{10}$ and $5 \times 10^{10} \mathrm{rad}$. The capsules were contained within a 41.4-mm-thick cylindrical lead shield. This shield was fabricated in order to limit the gamma dose compared to the neutron dose. The shield and capsule assembly was placed in a 127-mm-diam "I-hole" such that one capsule was near the top of the core and the other was on the midplane. The upper capsule was removed after one 14-day fuel cycle; the second, after two 14-day cycles.

\section{Radiation Dose Levels}

The calculation of neutron dose is difficult and depends on many factors, including the spectrum, element material percentages, and the range of recoil particles [7]. Preliminary calculations for CIT give a peak gamma dose $t r$, bismaleimide resin (Kerimid 601) of $2.2 \times 10^{\circ} \mathrm{rad}$ and a neutron dose of $9.0 \times 10^{\circ} \mathrm{rad}$, assuming that there is $4.1 \mathrm{wt} \%$ of hydrogen in the resin and that all of the recoil particle energy is deposited in the resin.

The dose levels for the two capsules in ATR were calculated by M. Jacox at INEL using a Monte Carlo code and will be compared to flux wire measurements. The average fast (>1 MeV) fluence was $6 \times 10^{17} \mathrm{n} / \mathrm{cm}^{2}$, and the average total fluence was $1.6 \times 10^{10} \mathrm{n} / \mathrm{cm}^{2}$ for capsule 1. The dose levels were as follows:

\begin{tabular}{lcc}
\hline & \multicolumn{2}{c}{ Dose (rad) } \\
\cline { 2 - 3 } Resin & Gamma & Neutron \\
\hline Spaulrad-S & $1.46 \times 10^{\circ}$ & $2.60 \times 10^{\circ}$ \\
PG5-1 & $1.53 \times 10^{\circ}$ & $2.72 \times 10^{\circ}$ \\
PG3-1 & $1.66 \times 10^{\circ}$ & $3.28 \times 10^{\circ}$ \\
\hline
\end{tabular}

\section{TEST RESULTS}

At this time only shear/compression testing has been done on the samples from capsule 1 and on a group of control specimens.

Ths small shear/compression test device and procedures were modified slightly for use in the hot cell at INEL. The Inconel backing pieces and insulation samples were first bonded together on one outside edge so that the three pieces could be handled as one assembly. The steel blocks were modified with vacuum holes to hold the assembly during installation and alignment.

The test results are given in Table III. In all tests, a compression of $345 \mathrm{MPa}$ was applied and then the shear load was incressed to failure. No significant loss of shear sirength was observed after irradiation.

Table III. Shear/compression test results

\begin{tabular}{|c|c|c|c|c|}
\hline & \multicolumn{4}{|c|}{$\begin{array}{l}\text { Shear streas (MPa) with } \\
\text { 345-MPa conpreasion }\end{array}$} \\
\hline & $\begin{array}{c}\text { Set } \\
1\end{array}$ & $\begin{array}{c}\text { Set } \\
2\end{array}$ & $\begin{array}{c}\text { Set } \\
3\end{array}$ & Average \\
\hline \multicolumn{5}{|l|}{ Spaulrad-S } \\
\hline Unirradiated & $90^{\circ}$ & 124 & 127 & 125 \\
\hline Capaule 1 & 127 & 127 & 132 & 129 \\
\hline \multicolumn{5}{|l|}{ PG5-1 } \\
\hline Unirrediated & 138 & 131 & 135 & 135 \\
\hline Cepaule 1 & 130 & 136 & 134 & 134 \\
\hline \multicolumn{5}{|l|}{ PG3-1 } \\
\hline Unirradiated & 121 & 127 & 121 & 123 \\
\hline Irradiated & 120 & 119 & 117 & 119 \\
\hline
\end{tabular}

\section{Fatigue Testing}

Fatigue testing was performed with a constant 345MPa compression and a shear load cycling at $5 \mathrm{~Hz}$ from approximately $14 \mathrm{MPa}$ to $90 \%$ of the lowest static shear stress at failure for the material. Six tests were planned for each material: three for a control group and three for a group irradiated in capsule 1. All of the Spaulrad$S$ and PG5-1 samples survived 30,000 cycles without failing. The peak cyclic shear stress on the Spaulrad-S samples was 112 MPs; on the PG5-1 samples, it was 117 MPa. The three unirradiated epoxy fatigue specimens failed during the cyclic testing after 300,900 , and 1400 cycles at peak loads of 108-, 108-, and 105-MPa shear stress. Testing of the irradiated PG3-1 was postponed uncil additional control specimens could be tested at lower stress levels. The results of the tests performed on the Spaulrad-S and PG5-1 samples are as follows:

\begin{tabular}{llll}
\hline & \multicolumn{3}{c}{ Shear stress after cycling (MPa) } \\
\cline { 2 - 4 } & Sample 1 & Sample 2 & Sample 3 \\
\hline Spaulrad-5 & & & \\
Unirradiated & 123 & 125 & 127 \\
Capsule 1 & 131 & 135 & 133 \\
PG5-1 & & & \\
Unirradiated & 130 & 132 & 129 \\
Ci ssule 1 & 128 & 132 & 128 \\
\hline
\end{tabular}


Length and Weight Measurements

The 18 shear/compression samples of each material were stacked, weighed, and measured to determine thickness and weight before and after irradiation. The epoxy PG3-1 developed a twist out of plane after irradiation. Figure $i$ shows this stack after irradiation. The measured increase in length is due to this twisting and not to swelling. The results were as follows:

\begin{tabular}{lll}
\hline & $\begin{array}{l}\text { Weight } \\
(\mathrm{g})\end{array}$ & $\begin{array}{c}\text { Thickness } \\
(\mathrm{mm})\end{array}$ \\
\hline $\begin{array}{l}\text { Spaulrad-S } \\
\text { Unirradiated }\end{array}$ & 5.80802 & 20.91 \\
Capgule 1 & $5.7812(-0.4 \%)$ & $20.74(-0.8 \%)$ \\
$\begin{array}{l}\text { PG5-1 } \\
\text { Unirradiated }\end{array}$ & 5.40832 & 18.66 \\
Capsule 1 & $54172(+0.2 \%)$ & $18.61(-0.3 \%)$ \\
$\begin{array}{l}\text { PG3-1 } \\
\text { Unirradiated }\end{array}$ & 5.19228 & 18.34 \\
Capsule 1 & $5.1229(-1.3 \%)$ & 19.38 (twisted) \\
\hline
\end{tabular}

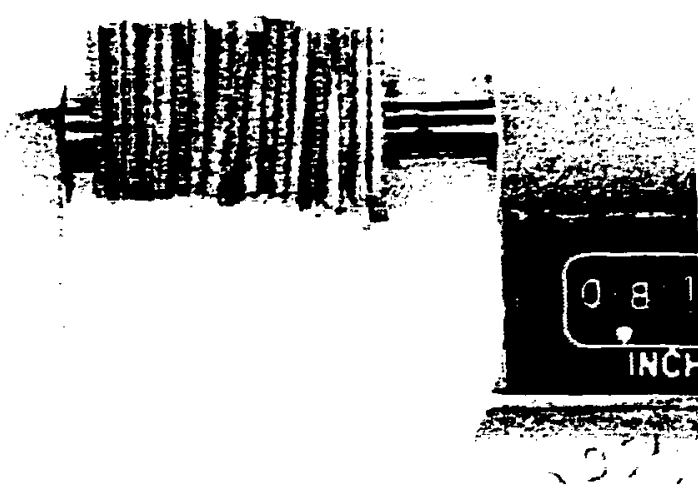

Fig. 7. Shear/compression samples after irradiation to $4 \times 10^{\theta} \mathrm{rad}$.

\section{CONCLUSIONS}

All of the commercial glasg-reinforced insulation sheet materials demonstrated high interlaminar shear strength (above $100 \mathrm{MPa}$ ) when tested in combination with $345 \mathrm{MPz}$ of compression. The Spaulrad-S and Shikishima PG5-1 systems with borsn-free glass and bismaleimide resin systems have shown no reduction in strength, statically or in fatigue, when tested in combined shear and compression after irradiation at room temperature to a total dose level of $4 \times 10^{9} \mathrm{rad}$ with over $60 \%$ of the dose from neutrons. The aromatic amine hardened epoxy PG3-1 showed some effects, such as darkening and warping, from the irradiation, but static strength was nearly the same. Further testing is needed for the epoxy system to verify the fatigue limits.

\section{ACKNOWLEDGMENT}

The results presented in this paper represent the contributions of a large number of people. While space does not permit mentioning all who have assisted, special credit should be given to Bob Majeski and Carl Lindemuth at Princeton for performing the screening testing, Darrel Sparks for performing the testing at INEL, Gene Kanemoto for coordinating the INEL work, and the cooperation of the vendors in supplying samples, particularly $T$. Hirokawa at Shikishima Canvas Co.

\section{REFERENCES}

[1] H. W. Blake (Oak Ridge National Laboratory), personal communication, May 1989.

[2] H. W. Blake, "Stress analysis of the Princeton Plasma Physics Laboratory $1 / 2$-in. by $1 / 2-$ in. shear/compression test fixture," in preparation, 1989.

[3] R. E. Schmunk, L. G. Miller, and H. Becker, "Tests on irradiated magnet insulator materials," J. Nucl. Mater., vols. 122 \& 123, pp. 1381-1385, 1984.

[4] R. Poehlchen, "The mechanical strength of irradiated electric insulation of superconducting magnets," presented at the ICMC Conference, Los Angeles, July 1989.

[5] S. Nishijima et al., "Development of radiation resistant composite materials for fusion magnets," presented at the ICMC Conference, Los Angeles, July 1989.

[6] W. Maurer, "Neutron and gamma irradiation effects on organic insulating materials for fusion magnets," IAEA TECDOC-417, Pp. 159-215, 1986.

[7] S. Egusa, "Effects of neutron irradiation on polymer matrix composites at $5 \mathrm{~K}$ and at room temperature," J. Nucl. Mater., vol. 148, PP. 43-52, 1987.

\section{DISCLAIMER}

This report was prepared as an account of work spunsored by an agency of the United States Government. Nesther the United Stales (juvernment nor any agency thereof. nur any of their employees, makes any warranty, express di inplied, or assumes any legal liability or responsibility for the accuracy. completeness. ur usefulness of any information, apparatus, product, or process disclused, or represents that its use would not infringe privately owned rights. Refer. ence herein to any specific commercial product, process, or service by trade name, trademark, manufacturer. or otherwise does not necessarily constutute or imply its endorsement, recommendation, or favoring by the United States Government or any agency thereof. The views and opinions of authors expressed herein do not necessarily state or reflect those of the United States Government or any agency thereof. 